\title{
LITERATURE REVIEW OF PERCEPTION, MATERNAL, PREGNANCY, AND LABOR IN 2015-2021
}

\author{
by \\ Eddy Siswanto ${ }^{1}$, Junardi Harahap ${ }^{2}$ \\ ${ }^{1,2}$ Department of Anthropology, Faculty of Social and Political Science, Padjadjaran University, Indonesia \\ ${ }^{1}$ Balai Besar Pelatihan Kesehatan (BBPK) Ciloto, Ministry of Health, Indonesia \\ Email: ${ }^{1}$ siswantoeddy2012@gmail.com
}

\begin{tabular}{l}
\hline \hline Article Info \\
\hline Article history: \\
Received \\
Revised \\
Accepted
\end{tabular}

Keywords:

Perception, Behavior,

Pregnancy, Labor

\begin{abstract}
PT)
The aim of this literature review was to find out any topics which had discussed and researched scientifically according to behavior, perception, maternal, pregnancy, and labor, especially in 2015 - 2021. The method of literature review was descriptive quantitative. Literatures were tracked by using Mendeley, then selected and processed by using VOS Viewer. They were also manually processed according to completeness of each literature. Of the 4 main discussion clusters had been found, i.e. target clusters, mothers, risk groups, and health services, there were determined several main topics and keywords i.e: examination (care), mothers, factors, experiences, childbirth, and antenatal care. Meanwhile, topics those rarely discussed or researched were perceptions and adolescents. The most collected literatures were published in 2019 (29\%), followed by $2020(22 \%)$, and $2015(15 \%)$. Most of the research or studies of the collected literatures were conducted descriptively and took research locations in Indonesia and African countries. Of the selected literatures rose basic assumption that the high maternal mortality rate, especially in Indonesia, is closely related to the lack of utilization of health facilitaties, as a result of the improper behavior of pregnant women in maintaining pregnancy and labor. This behavior is based on mindsets and perceptions related to pregnancy and labor, which have been formed since the pregnant women were teenagers. ( $9 \mathrm{pt}$ ).
\end{abstract}

This is an open access article under the CC BY-SA license.

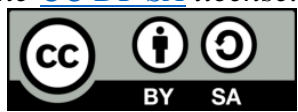

\section{Corresponding Author:}

Eddy Siswanto

Department of Anthropology, Faculty of Social and Political Science, Padjadjaran University, Indonesia

Email: siswantoeddy2012@gmail.com

\section{INTRODUCTION}

The high rate of maternal and new born mortality become main problems which are difficult to solve in Indonesia. Around 2 mothers and 8 babies are born and die hourly in Indonesia. In 2015, the maternal mortality rate in Indonesia was around 305 per 100,000 live births, even the newborn mortality rate in 2017 reached 15 per 1,000 live births. In total, there were 4,912 cases of maternal death in 2016, compared to 2015 of 4,999 cases. In the first semester of 2017, the number has reached 1,712 cases of death. Based on a follow-up study of the population census in 2010, it was found that the proportion of maternal deaths that occurred in the postpartum period was $57 \%$, during pregnancy $22 \%$, and at the time of delivery was $15 \%$.

So many efforts have been conducted to reduce maternal and infant mortality, but those have not provided optimal results. Various counselling and education of reproductive health were very intensively carried out in several areas [1]-[5]. Socialization of Maternal Health and distribution of Maternal Books in the community, in order to increase the mothers' knowledge of healthy pregnancy and labour, have been carried out to the basic layers of society [6]-[8]. Even though Maternal Book could significantly increase knowledge in certain community groups, but it was still not enough to reduce maternal mortality rate in the community [9]-[17].

Conducting partnership between midwives and traditional birth attendants, such as dukun beranak or paraji, had also been carried out by several regions in Indonesia, especially in West Java [18]-[21]. Even local policy makers are responsible for resolving the high maternal mortality rate, by making local regulations related to this partnership [22]. Training for traditional birth attendants and the provision of health school scholarships for traditional birth 
attendants' children, were carried out in certain areas, so that the community would no longer depend on traditional birth attendants to manage deliveries [23]. But finally, it would be depend on mothers' decision to behave healthier when managing their pregnancy and labor.

Behaviour determines health status in community, especially for women and young girl's [24]-[26]. On the other hand, behaviour is formed and starts from prejudice. So, prejudice greatly affects a person's perception of an object. Which in turn will affect a person in behaving and behaving towards something in their environment [27]. Perception is the basis for a person's behavior, especially behavior during pregnancy and childbirth [19], [28]-[31].

But have all of these things been internationally discussed, studied, or even scientifically documented? Which have of these things been discussed and researched according to behavior, perception, maternal, pregnancy, and childbirth? Were these topics still main focus in research, nationally or internationally? So, to found out, it is necessary to conduct literature review of the latest scientific papers.

The aim of this literature review was to find out any topics which had discussed, researched, and scientifically published according to behavior, perception, maternal, pregnancy, and labor, in 2015 to 2021. Spesifically, the literature review was conducted to get main ideas, types of research, research locations, novelty, research subjects and objects that have not been or rarely studied. Then it abstracted the main overview of what was discussed, the concepts written, along with the data and facts involved.

This literature review provided basic data for research related to Maternal and Child Health (MCH), especially for reduction program of maternal mortality rate in Indonesia. This literature review could specifically contribute for researches related to the behavior of pregnant women and young women towards pregnancy and childbirth. This literature review was also expected to be the basis for further research related to the behavior of pregnant and lactating mothers in Indonesia. It can be immediately followed up with various appropriate and effective health programs for teenage girl and pregnant women in Indonesia.

\section{RESEARCH METHOD}

This literature review used descriptive quantitative method by using internet and softwares. Scientific literatures were tracked by using Mendeley, targeting to nationally or internationally indexed of scientific publications. They were also tracked using the keywords i.e., perception, maternal, pregnancy, and labor. The result was then selected based on publications between 2015 and 2021. The literatures were also selected by title and abstraction, based on the relationship between content and the basic idea of behavior of pregnant women and teenage girl towards pregnancy and childbirth.

The selected literatures were then processed by using VOS Viewer to identified relevance of ideas, distribution of novelties, and look for topics those were much discussed. It also determined topics those were rare or never been discussed.

In addition, the selected literatures were also manually decribed, according to completeness of the literature, the type of publication, the name of scientific journal, publisher, author, volume and issue, and year of publication. The results will be discussed descriptively, especially determining the subjects and objects of research that are widely discussed by the selected literature. The contents of each selected literature were then abstracted to obtain an overview of what was discussed, the concepts written, along with the data and facts involved.

\section{RESULTS AND ANALYSIS}

\subsection{Results}

Scientific literatures were tracked using Mendeley on March 6, 2021 based on keywords: perception, maternal, pregnancy, and birth. Around 645 literatures were obtained. Using the same tool, then selection was made based on the year of publication, which is between 2015 and 2021, and 320 literatures were obtained. By viewing both the title and the available abstract, then 72 literatures were selected based on perception, maternal, pregnancy, and labor. Using the VOS Viewer, the 72 literatures were then processed and the following results were obtained: 


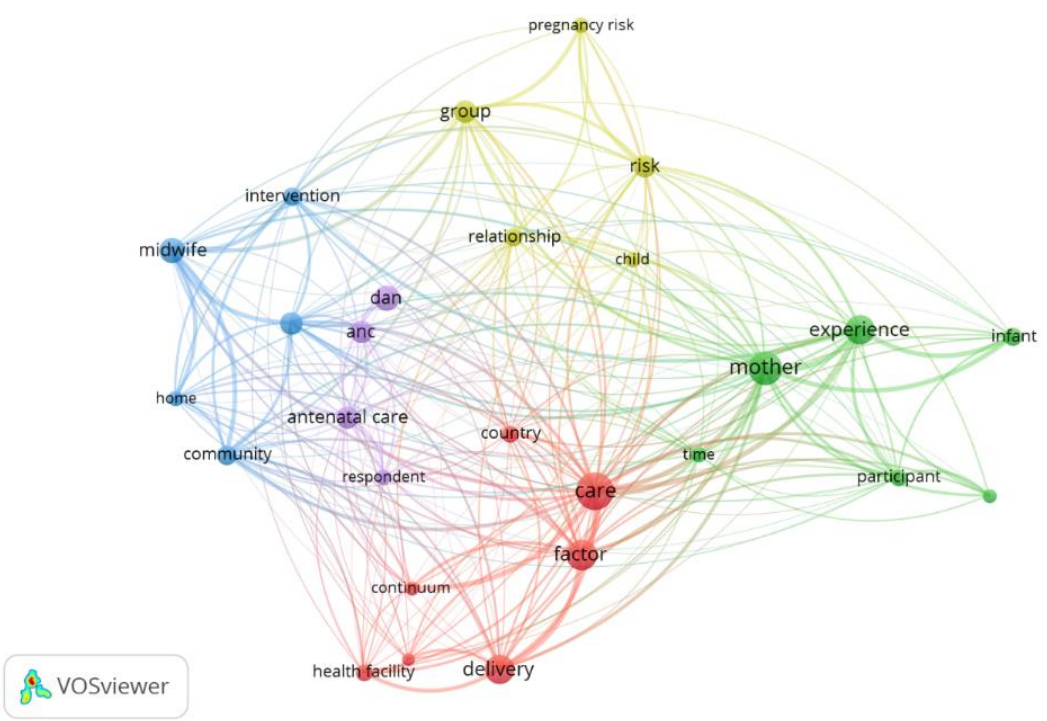

Figure 1. Interrelation of key words and research topics

The figure shows there were 4 main discussion clusters from the literature studied, i.e. target clusters, mothers, risk groups, and health services. There were several main topics and keywords that have a lot of relevance to other topics, marked by a larger circle, i.e., mother, care, experience, factor, and delivery. Then it can also be seen the distribution of the novelty or the year of publication of the literature as below:

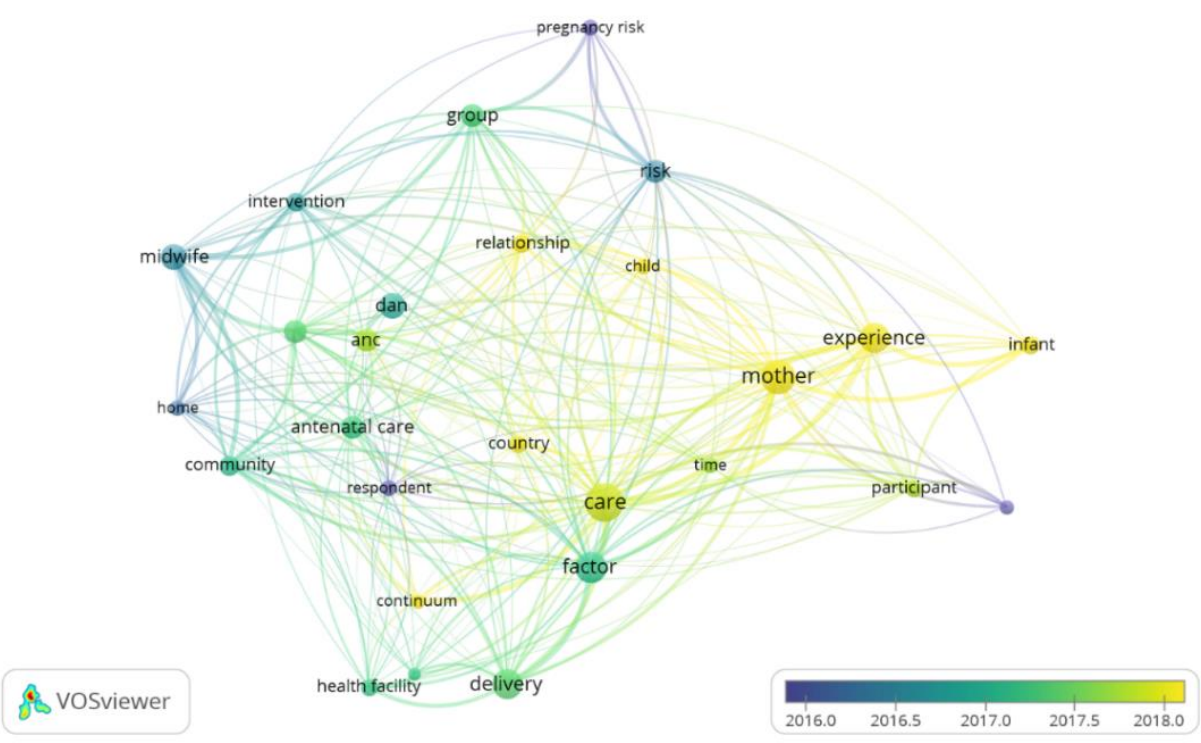

Figure 2. Interrelation of key words, research topics, and published year

The figure shows more of literatures were published in 2018 and above, discussing about mothers, experiences, examinations and mother-infant interactions. Meanwhile, topics related to maternal services, targets, risks, and facilitation of health services are widely discussed in the literature which published before 2018. Of the 72 literatures, there were only 59 complete literatures, both the contents of the publication, and other matters related to the publication itself, such as the name of the publisher, etc. This result was appropriate with the manual processing which the most tracked literature was published in 2018 as shown in the figure below: 


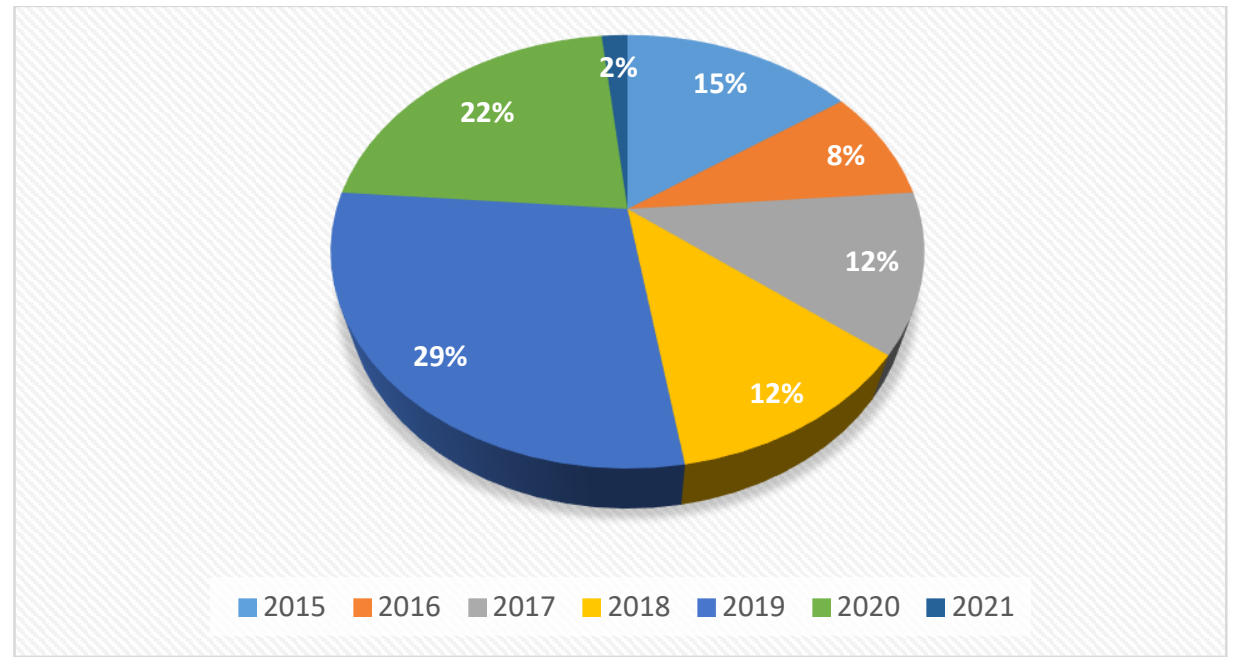

Figure 3. Precentage of selected literatures based on published year

The figure shows the most collected literatures were published in 2019 (29\%), followed by 2020 (22\%), and $2015(15 \%)$. Then the VOS Viewer also gives the results of which topics are the most discussed from all the collected literature, as can be seen in the figure below:

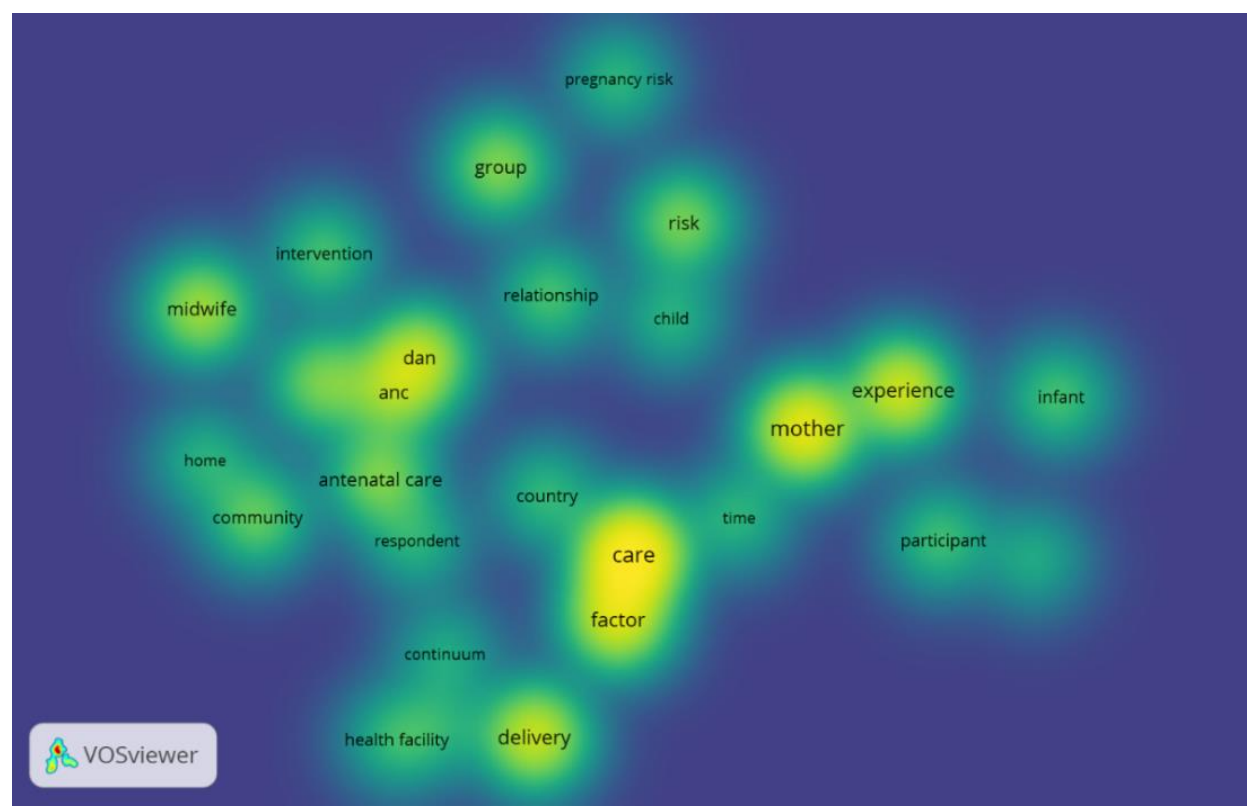

Figure 4. Main topics of literatures

The figure shows, the bigger and brighter of the point, the more discussed was the topic. The topic was more researched focus of all the collected literatures. These topics were care, mother, factor, experience, delivery, and antenatal care. Meanwhile, topics those were rarely researched are perceptions and adolescents. In fact, it is clear that one of the keywords used in literature tracking is perception. Manually, by comparing the title and the things discussed in the abstract, it shows that perceptions are widely discussed as the focus of research, but not perceptions about pregnancy or childbirth itself, and are more specific to things related to pregnancy or delivery, such as perceptions of sex. pre-marriage, perceptions of health services received, options for pregnancy check-ups, etc. More details can be seen in the figure below: 


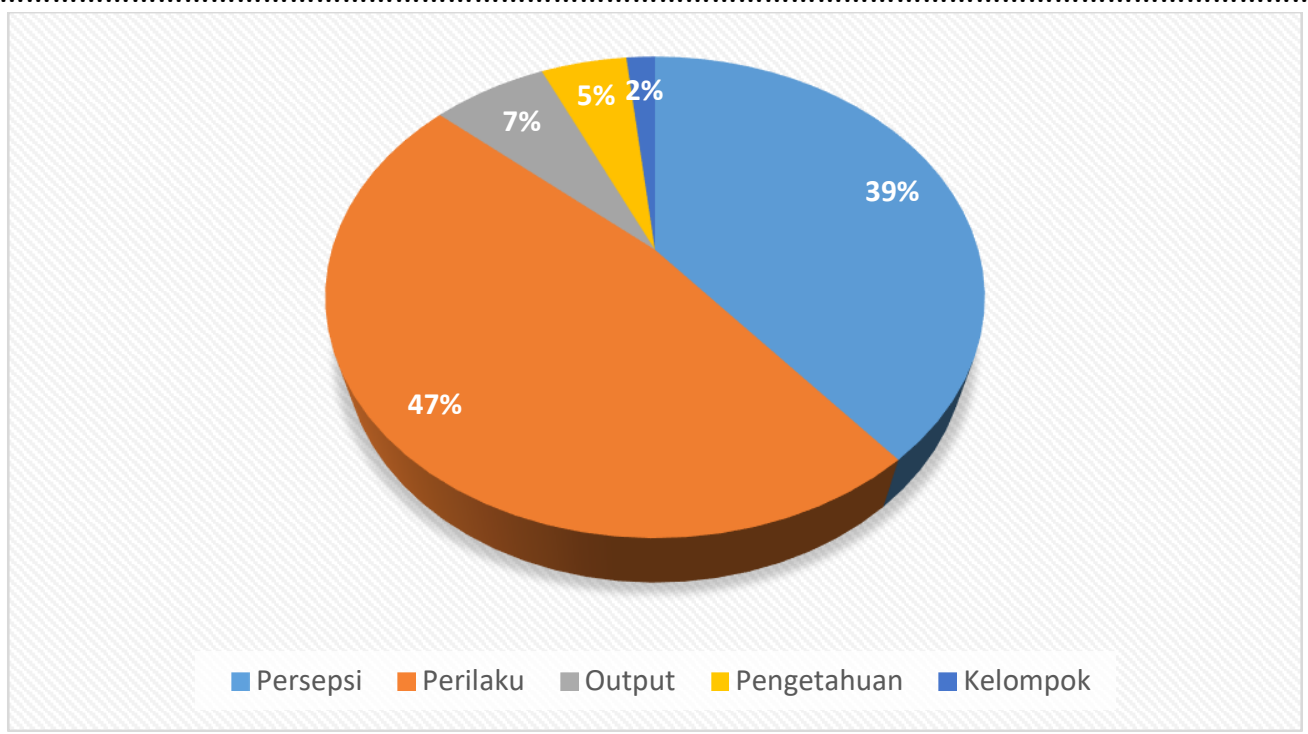

Figure 5. Precentage selected literatures based on research topics

The figure shows about $39 \%$ of the topic in the collected literatures was perception but not according to pregnancy or delivey. While around $47 \%$ of the literatures examined behaviour of the respondents, and not specific about perceptions. $56 \%$ of the research was carried out descriptively, $39 \%$ of the research was analytic, while the rest was literature review and others. Meanwhile, the most research used quantitative methods (59\%), followed by qualitative methods (31\%), and the rest are combined methods, literature studies, and others. Most of the research or studies took research locations in Indonesia, then in African countries, and some others from Europe, Asia, and literature reviews. More details can be seen in the figure below:

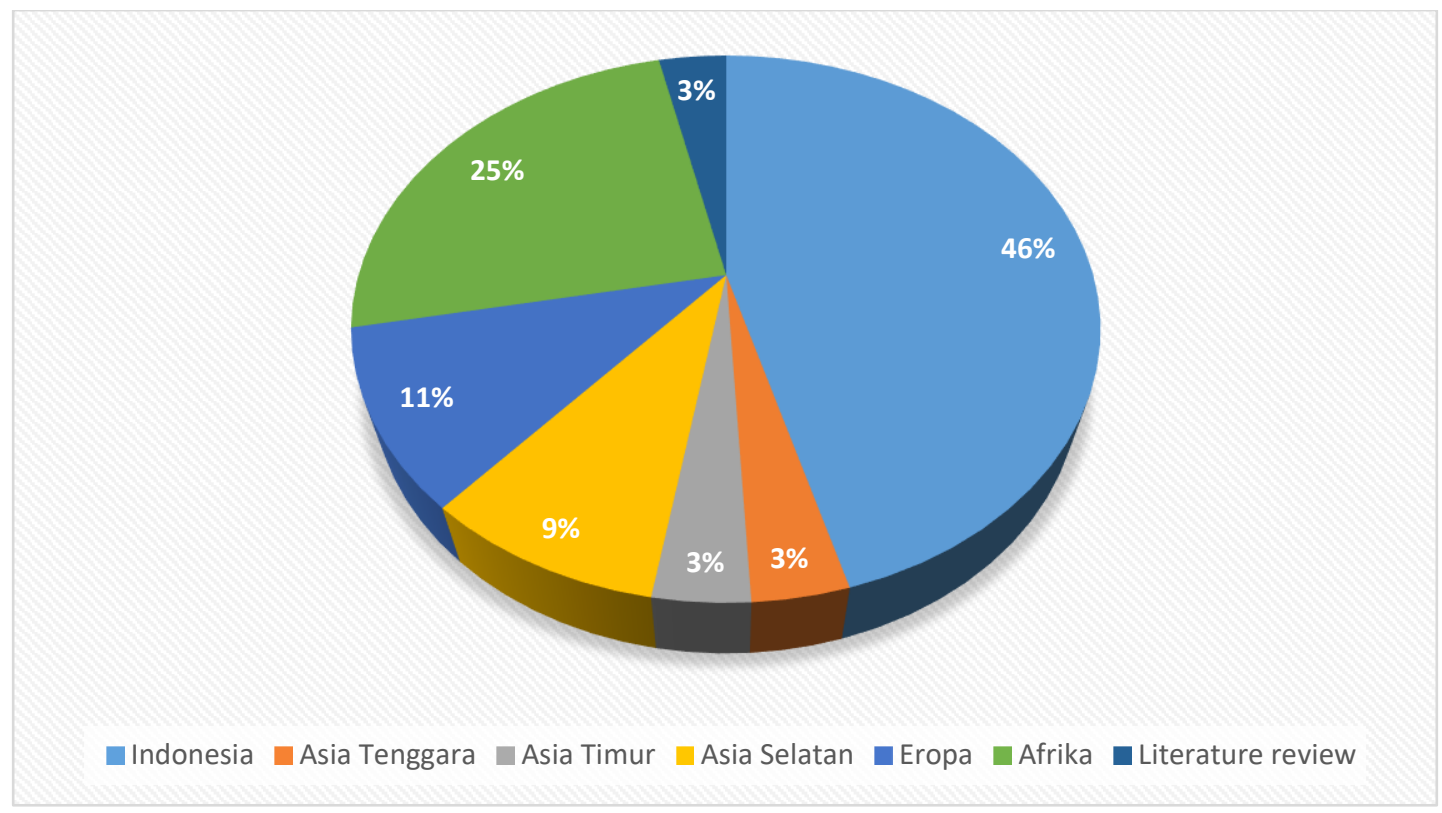

Figure 6. Precentage selected literatures based on research locus

The figures shows around $46 \%$ of the literature came from Indonesia, about $25 \%$ came from African countries, and the rest came from other Asian, European, and literature studies. Meanwhile, the research subjects which widely discussed in the collected literatures were the utilization of health facilities (utilisasi), pregnancy examination (care), and preference (preferensi). More details can be seen in the word cloud in Bahasa Indonesia below: 


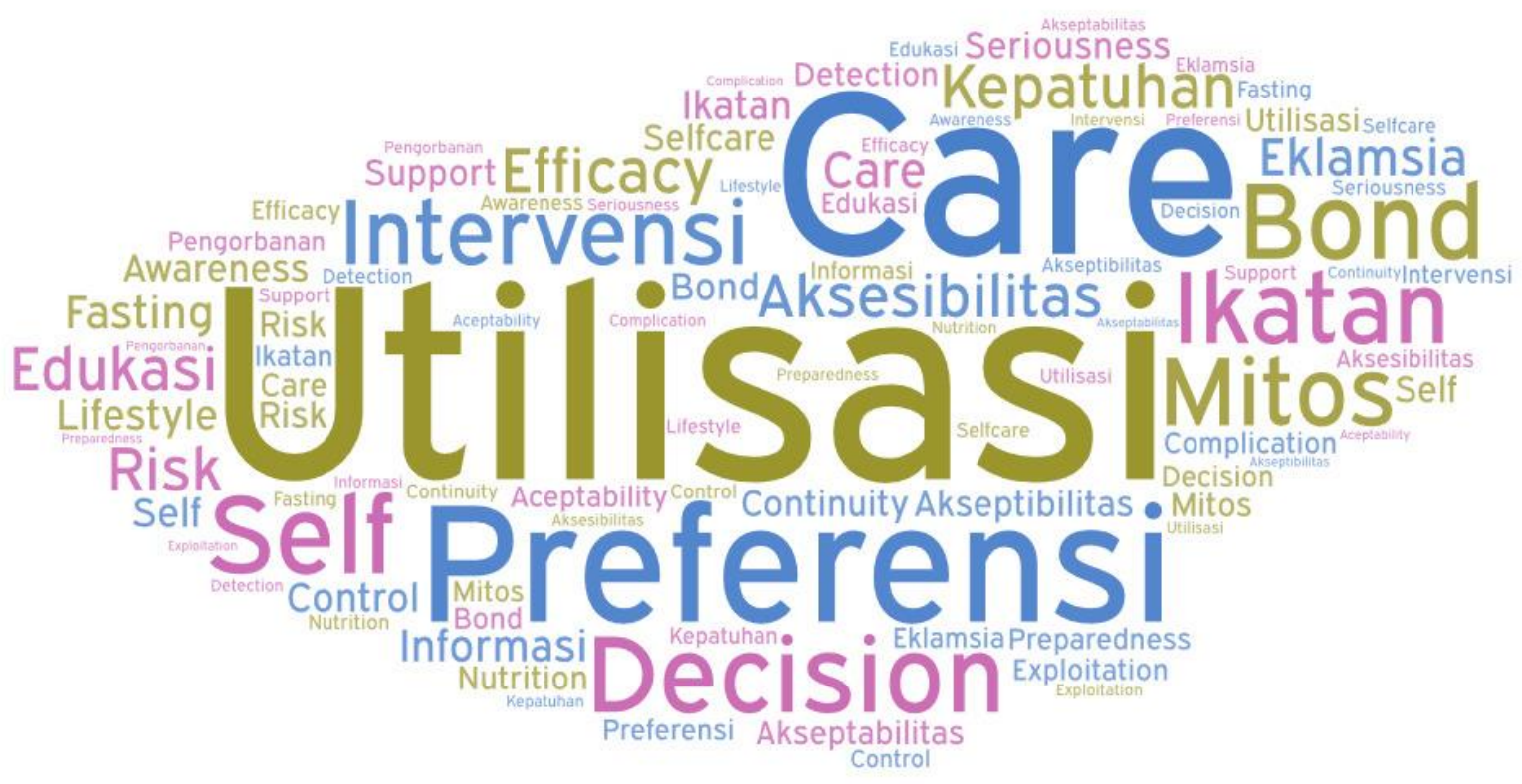

Figure 7. Research Subjects

Meanwhile, the objects of research/study which widely discussed in the collected literature were pregnancy (kehamilan), culture (budaya), health worker (nakes), husband (suami), and influencing factors (faktor). For more details, see the word cloud in Bahasa Indonesia below:

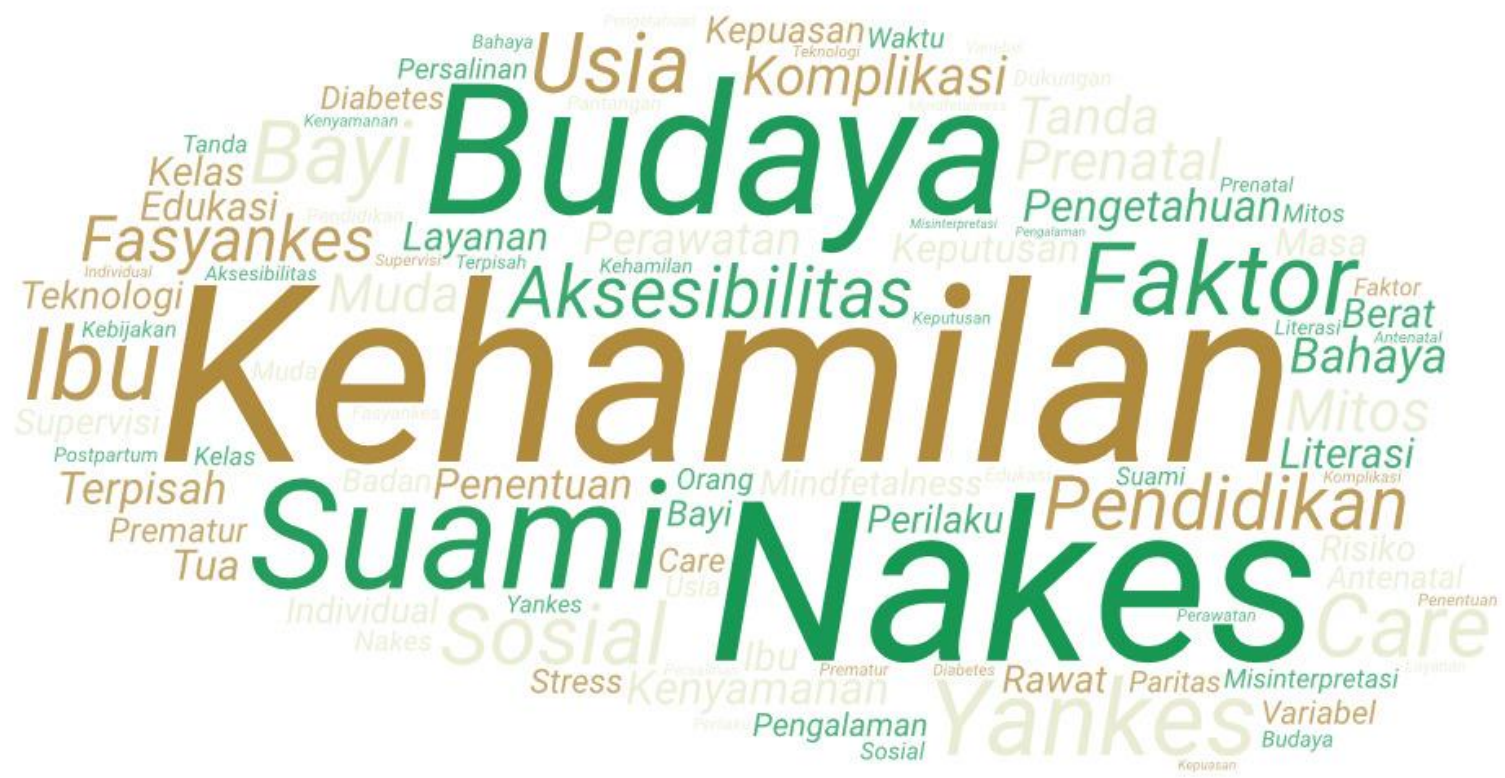

Figure 8. Research Objects

\subsection{Literature Overview}

Most of literatures discussed about behavior of mothers to get antenatal examination and giving birth outside health care facilities. The lack utilization of standardized health care facilities, both government and private facilities by mothers, occured in various parts of the world [11], [32]-[40]. This was not always being of independent behavior from mothers. But it was also related to decision-making process in seeking health services in family when mothers were pregnant or giving birth [41]-[49]. The role of knowledge, personal feelings, circulating myths, support from 
International Journal of Social Science (IJSS)

Vol.1 Issue.3 October 2021, pp: 159-170

ISSN: 2798-3463 (Printed) | 2798-4079 (Online)

DOI: https://doi.org/10.53625/ijss.v1i3.408

husbands, families, and the community, greatly influenced the decision to get antenatal care and giving birth in health care facilities [30], [50]-[55].

Other factor which influenced mothers to get their pregnancies examination and giving birth besides health care facilities, was the family's economic situation as the main factor, apart from social conditions, accessibility of health care facilities, acceptance of health services, culture and traditions in the community, etc. [56]-[60].

However, the main point which affected the decision making was mother's perception of pregnancy and childbirth, along with the consequences of the knowledge and decisions indeed [61]-[65]. This perception, of course, did not appear suddenly. But it was growing and formed since they were teenagers. Local culture and traditions were another factors which very close to mothers in shaping their perceptions, especially in terms of maintaining pregnancy or dealing with childbirth. Together with other social experiences in the community, this would shape the perception of mothers since they were teenagers. On the other hand, educational status also affected the reasoning power of mothers or equiped teenager girls in managing pregnancy and childbirth. Some literature shown that positive behavior and perception of pregnancy or childbirth were found in higher educational status of mothers [66]. Likewise with the dissemination of reproductive health materials, this also affected the formation of positive perceptions among teenager girls regarding pregnancy and childbirth that they will face [1], [29], [67], [68].

Personal experience related to health services obtained during pregnancy and childbirth, especially regarding the behavior of health workers who serve them, greatly influences the mother's decision to get antenatal care and giving birth to a health facility [28], [31], [69]-[77]. Likewise, mothers' knowledge according to availability and accessibility of health facilities in the community was a determining factor to form behavior for getting antenatal care and giving birth to the right place [78]. In fact, it supports mothers independently to manage their pregnancy and childbirth better and safely [79]-[82].

Indirectly, the description above is appropriate with formation of health problems in Blum's theory [26]. H.L. Theory Blum stated that health status is largely determined by environmental factors (40\%), behavioral factors (30\%), health care factors (20\%), and only $10 \%$ from genetic factors (heredity). Behavior has a big role in the emergence of health problems, especially in high maternal mortality rate in the community [24]. As already discussed, this behavior is closely related to the perceptions of the perpetrators, in this case is the mothers.

From the results above, the basic assumption arises that the high maternal mortality rate, especially in Indonesia, is closely related to the lack of utilization of health facilitaties as a result of the inappropriate behavior of pregnant women in maintaining pregnancy and childbirth [83]-[85]. This behavior is based on mindsets and perceptions related to pregnancy and childbirth, which have been formed since the pregnant women were teenagers.

\section{CONCLUSION}

The main ideas that became the topic of research focus which based on the keywords perception, maternal, pregnancy, and birth, during the period between 2015 to 2015 were the examination (care), mother, factors, experience, delivery, and antenatal care. Most research related to maternal and child health is descriptive (56\%), while the most widely used method is quantitative method (59\%). Most (46\%) of the literature took research locations in Indonesia, where $29 \%$ of the literature was published in 2019 , followed by $22 \%$ in 2020 . The subjects of research/study which most discussed in the collected literature were the utilization of health facilities, antenatal care, and preference. While the most research objects were pregnancy, culture, and health workers. Only teenager girls as well as perception related to pregnancy and childbirth, were not even discussed in these articles.

The results of literature overviewing shown that the high maternal mortality rate was closely related to the lack utilization of health facilitation as result of the inapproriate behavior of pregnant women in maintaining pregnancy and dealing her childbirth. This was based on mindsets and perceptions related to pregnancy and childbirth, which had been formed since the pregnant women were teenagers.

It is necessary to conduct further research related to the perception of teenage girls and the behavior of pregnant women in Indonesia, to be immediately followed up with various appropriate and effective health programs, both for teenage girls and pregnant women in Indonesia.

\section{ACKNOWLEDGEMENTS}

I am grateful to Junardi Harahap, Ph.D. as my research supervisor for my post graduate study in Padjadjaran University. We are grateful to the Director of Balai Besar Pelatihan (BBPK) Ciloto, MOH, for his permition and support for this study. We are also grateful to all contibutors in completing literature collection in this study. Finally, we would also grateful to all staff of this journal for their support to publishing this article. 


\section{REFERENCES}

[1] N. Fatkhiyah, M. Masturoh, and D. Atmoko, "Edukasi Kesehatan Reproduksi Remaja," J. Abdimas Mahakam, vol. 4, no. 1, pp. 84-89, Jan. 2020, doi: 10.24903/jam.v4i1.776.

[2] A. Johariyah and T. Mariati, "Efektivitas Penyuluhan Kesehatan Reproduksi Remaja Dengan Pemberian Modul Terhadap Perubahan Pengetahuan Remaja," J. Manaj. Kesehat. Yayasan RS.Dr. Soetomo, vol. 4, no. 1, 2018, doi: 10.29241/jmk.v4i1.100.

[3] A. Buaton, A. S. Sinaga, and M. A. Sitorus, "Pengetahuan Remaja dan Keterpaparan Informasi Remaja Tentang Kesehatan Reproduksi,” Sci. Period. J. Public Heal. Coast. Heal., vol. 2, no. 2, 2019.

[4] V. Lamama, S. Solang, and M. Korompis, "Pengaruh Penyuluhan Tentang Pemeriksaan Kehamilan Terhadap Peningkatan Pengetahuan Ibu Hamil," J. Ilm. Bidan, vol. 3, no. 1, 2015.

[5] N. Benita, J. Dewantiningrum, and N. Maharani, "PENGARUH PENYULUHAN TERHADAP TINGKAT PENGETAHUAN KESEHATAN REPRODUKSI PADA REMAJA SISWA SMP KRISTEN GERGAJI,” J. Kedokt. Diponegoro, vol. 1, no. 1, 2012.

[6] D. Leyva, A. von Suchodoletz, D. Shroff, A. Hinojo, and J. Kärtner, "Maternal book-sharing styles and goals and children's verbal contributions in three communities," Early Child. Res. Q., vol. 54, 2021, doi: 10.1016/j.ecresq.2020.09.010.

[7] Kementrian Kesehatan RI, "BUKU KIA KESEHATAN IBU DAN ANAK bagian ibu," Katalog Dalam Terbitan. Kementerian Kesehatan RI, 2020. .

[8] K. K. RI, Buku Kesehatan Ibu dan Anak. 2017.

[9] M. Krull and D. Kurniasari, "GAMBARAN FAKTOR KELENGKAPAN PENCATATAN BUKU KESEHATAN IBU DAN ANAK (KIA) OLEH BIDAN DI PUSKESMAS DI KOTA KUPANG PROVINSI NUSA TENGGARA TIMUR," Arch. COMMUNITY Heal., vol. 7, no. 2, 2020, doi: 10.24843/ach.2020.v07.i02.p05.

[10] A. D. Erawati, N. Alfiani, and D. Kurniasih, "Pengetahuan Ibu Hamil tentang Buku Kesehatan Ibu dan Anak (KIA) (Study Kasus di BPM Noor Naini Kelurahan Podorejo Kota Semarang),” J. Ilm. Kesehat., vol. 19, no. 02, 2020, doi: 10.33221/jikes.v19i02.474.

[11] R. Dumilah, "Umur, interval kehamilan, kehamilan yang diinginkan dan perilaku pemeriksaan kehamilan," J. Penelit. Kesehat. Suara Forikes, vol. 10, no. 2, 2019.

[12] E. R. Wijhati, "Pemanfaatan buku Kesehatan Ibu dan Anak pada ibu hamil di puskesmas," J. Kebidanan dan Keperawatan Aisyiyah, vol. 15, no. 1, 2019, doi: 10.31101/jkk.1002.

[13] M. Masrul, "Profil kepemilikan dan tingkat pengetahuan ibu-ibu tentang buku kia di Kabupaten Padang Pariaman," Maj. Kedokt. Andalas, vol. 42, no. 2, 2019, doi: 10.25077/mka.v42.i2.p50-55.2019.

[14] S. Subiyatun, "Gambaran Pemanfaatan Buku Kesehatan Ibu dan Anak (KIA) Oleh Ibu Hamil,” J. Kebidanan dan Keperawatan Aisyiyah, vol. 13, no. 2, 2018, doi: 10.31101/jkk.403.

[15] S. Khuzaiyah, M. Khanifah, and N. Chabibah, "Evaluasi Pencatatan \& Pemanfaatan Buku Kesehatan Ibu dan Anak (KIA) Oleh Bidan, Ibu dan Keluarga,” Indones. J. Nurs. Pract., vol. 2, no. 1, 2018, doi: 10.18196/ijnp.2175.

[16] A. Donsu, S. Tombokan, A. Montolalu, and G. Tirtawati, "Hubungan Pendidikan Dan Pengetahuan Ibu Hamil Dengan Penggunaan Buku Kesehatan Ibu Dan Anak (KIA)., J. Ilm. Bidan, vol. 4, no. 2, 2016.

[17] C. Sistiarani, E. Gamelia, and D. U. P. Sari, "Fungsi Pemanfaatan Buku KIA terhadap Pengetahuan Kesehatan Ibu dan Anak pada Ibu," Kesmas Natl. Public Heal. J., vol. 8, no. 8, 2014, doi: 10.21109/kesmas.v8i8.404.

[18] Yuridis.id, "Pengaturan Hukum Tentang Dukun Beranak," Yuridis.id, 2019. https://yuridis.id/pengaturanhukum-tentang-dukun-beranak/ (accessed Mar. 16, 2021).

[19] P. Damayanti, "Persepsi Ibu Hamil Tentang Kehamilan Resiko Tinggi di atas usia 35 tahun," Persepsi Ibu Hamil Tentang Kehamilan Resiko Tinggi Di Desa Begawat Kec. Bumijawa Kabupaten Tegal Tahun 2016, vol. 1, no. 2015, 2015.

[20] Tempo.co, “Tekan Kematian Bayi , Kemampuan Paraji Ditingkatkan,” Tempo.co, 2012. https://nasional.tempo.co/read/431551/tekan-kematian-bayi-kemampuan-paraji-ditingkatkan/full\&view=ok (accessed Mar. 17, 2021).

[21] P. Cisoka, "Kemitraan bidan dan dukun," Situs Web Resmi BLUD Puskesmas Cisoka Kabupaten Tangerang, 2011. http://dinkes.tangerangkab.go.id/cisoka/2017/10/17/kemitraan-bidan-dan-dukun/ (accessed Mar. 16, 2021).

[22] B. Sukabumi, "Peraturan Daerah Kemitraan Bidan, Paraji, dan Kader Kesehatan." Pemerintah Daerah Kabupaten Sukabumi, Sukabumi, pp. 1-20, 2013.

[23] K. Jatim, "DUKUN BAYI DIBERI PELATIHAN MEDIS, ANAKNYA DAPAT BEASISWA SEKOLAH 
International Journal of Social Science (IJSS)

Vol.1 Issue.3 October 2021, pp: 159-170

ISSN: 2798-3463 (Printed) | 2798-4079 (Online)

DOI: https://doi.org/10.53625/ijss.v1i3.408

KESEHATAN http://kominfo.jatimprov.go.id/read/umum/27216,” Kominfo Jatim, 2014.

http://kominfo.jatimprov.go.id/read/umum/27216 (accessed Mar. 16, 2021).

[24] K. K. R. Biro Komunikasi dan Pelayanan Masyarakat, "Bersama Selesaikan Masalah Kesehatan,"

Kementerian Kesehatan RI, 2018. https://www.kemkes.go.id/article/view/18012900004/together-

overcoming-health-problem-.html\#: :text=Teori klasik H. L.,) faktor genetik (keturunan). (accessed Oct. 17, 2018).

[25] K. Anam, "Pendidikan Perilaku Hidup Bersih dan Sehat dalam Presfektif Islam," J. Sagacious, vol. 3, no. 1, 2016.

[26] D. Wawan, A. \& M., Teori dan Pengukuran Pengetahuan, Sikap, dan Perilaku Manusia. 2016.

[27] P. News, “TEORI PRASANGKA,” dayaknews.blogspot.com, 2008. http://dayaknews.blogspot.com/2008/12/teori-prasangka_27.html (accessed Oct. 17, 2020).

[28] S. Dewi, Y. Romalita, Y. Yusriani, and M. K. Alwi, "Perceptions of pregnant woman on monetary and time sacrifice for satisfaction based on health workers roles in antenatal services to reduce the risk of maternal death at Gowa district," Heal. Sci. J. Indones., vol. 10, no. 2, 2019, doi: 10.22435/hsji.v10i2.2444.

[29] A. Akselsson, S. Georgsson, H. Lindgren, K. Pettersson, and I. Rådestad, "Women's attitudes, experiences and compliance concerning the use of Mindfetalness- a method for systematic observation of fetal movements in late pregnancy," BMC Pregnancy Childbirth, vol. 17, no. 1, p. 359, Dec. 2017, doi: 10.1186/s12884-017-1548-5.

[30] H. Muthoharoh, "Persepsi Ibu Hamil Tentang Budaya Dan Mitos Kehamilan di Wilayah Kerja Puskesmas Padangan Kabupaten Bojonegoro," J. Midpro, vol. 7, no. 2, p. 55, Dec. 2015, doi: 10.30736/md.v7i2.126.

[31] M. Qudriani and S. N. Hidayah, "Persepsi Ibu Hamil Tentang Kehamilan Resiko Tinggi Dengan Kepatuhan Melakukan Antenatal Care Di Desa Begawat Kecamatan Bumijawa Kabupaten Tegal Tahun 2016," 2nd Semin. Nas. IPTEK Terap., vol. 1, no. 2015, 2015.

[32] H. McCauley, D. M. McCauley, D. G. Paul, and N. Van Den Broek, "“We are just obsessed with risk': Healthcare providers' views on choice of place of birth for women," Br. J. Midwifery, vol. 27, no. 10, 2019, doi: 10.12968/bjom.2019.27.10.633.

[33] R. C. Onoh, J. O. Egede, L. O. Lawani, K. C. Ekwedigwe, L. O. Aja, and B. O. Anozie, "Birth preparedness and complication readiness among women of reproductive age group in Abakaliki, Southeast Nigeria,"

Niger. J. Clin. Pract., vol. 23, no. 3, 2020, doi: 10.4103/njcp.njcp_670_18.

[34] I. Dharmayanti, K. Azhar, D. H. Tjandrarini, and P. S. Hidayangsih, "PELAYANAN PEMERIKSAAN KEHAMILAN BERKUALITAS YANG DIMANFAATKAN IBU HAMIL UNTUK PERSIAPAN PERSALINAN DI INDONESIA,” J. Ekol. Kesehat., vol. 18, no. 1, 2019, doi: 10.22435/jek.18.1.1777.6069.

[35] A. M. A. Fatali and B. Budyanra, "VARIABEL-VARIABEL YANG MEMENGARUHI STATUS KUNJUNGAN PEMERIKSAAN KEHAMILAN (ANTENATAL CARE) DI PROVINSI PAPUA TAHUN 2017 (ANALISIS REGRESI LOGISTIK BINER),” Semin. Nas. Off. Stat., vol. 2020, no. 1, 2021, doi: 10.34123/semnasoffstat.v2020i1.406.

[36] Y. Rokayah and S. Rusyanti, "PERSEPSI DAN SIKAP IBU HAMIL TERHADAP PEMANFAATAN PELAYANAN ANTE NATAL CARE (ANC) OLEH BIDAN DI WILAYAH I PUSKESMAS KABUPATEN LEBAK TAHUN 2016,” J. Med. (Media Inf. Kesehatan), vol. 4, no. 1, 2017, doi: 10.36743/medikes.v4i1.66.

[37] R. S. Nasution and H. P. Harahap, "Faktor-Faktor yang Berhubungan dengan Keikutsertaan Pelaksanaan Kelas Ibu Hamil," J. Ilm. Kebidanan Indones., vol. 10, no. 01, 2020, doi: 10.33221/jiki.v10i01.427.

[38] Y. Ariestanti, T. Widayati, and Y. Sulistyowati, "Determinan Perilaku Ibu Hamil Melakukan Pemeriksaan Kehamilan (Antenatal Care) Pada Masa Pandemi Covid-19,” J. Bid. Ilmu Kesehat., vol. 10, no. 2, 2020.

[39] E. Guspaneza and E. Martha, "Pengaruh Perilaku Ibu Selama Kehamilan terhadap Status Kehamilan yang Tidak Diinginkan di Indonesia," Media Kesehat. Masy. Indones., vol. 15, no. 4, 2019, doi: 10.30597/mkmi.v15i4.7986.

[40] L. I. Dini, P. Riono, and N. Sulistiyowati, "PENGARUH STATUS KEHAMILAN TIDAK DIINGINKAN TERHADAP PERILAKU IBU SELAMA KEHAMILAN DAN SETELAH KELAHIRAN DI INDONESIA (ANALISIS DATA SDKI 2012)," J. Kesehat. Reproduksi, vol. 7, no. 2, 2016, doi: 10.22435/kespro.v7i2.5226.119-133.

[41] J. K. Ganle, E. Otupiri, M. Parker, and R. Fitzpatrick, "Socio-cultural Barriers to Accessibility and Utilization of Maternal and Newborn Healthcare Services in Ghana after User-fee Aboli- tion," Int. J. Matern. Child Heal., vol. 3, no. 1, 2015. 
[42] F. A. Ababulgu and T. T. Bekuma, "Delivery Site Preferences and Associated Factors among Married Women of Child Bearing Age in Bench Maji Zone, Ethiopia," Ethiop. J. Health Sci., vol. 26, no. 1, 2016, doi: 10.4314/ejhs.v26i1.9.

[43] R. M. Maia Feitosa, R. D. Pereira, T. J. Costa de Paula Souza, R. J. Moreira de Freitas, S. A. Rodrigues Cabral, and L. F. de França Souza, "Factors that influence the choice of birth type regarding the perception of puerperal women.," Rev. Pesqui. Cuid. e Fundam., vol. 9, no. 3, 2017.

[44] M. Khanam and N. Jafrin, "Determinants of Maternal Care Utilization in a Rural Area of Bangladesh: A Case Study of Udaypur Village of Bagerhat District," Glob. J. Med. Res., vol. 17, no. 3, 2017.

[45] Y. Agus, S. Horiuchi, and M. Iida, "Women's choice of maternal healthcare in Parung, West Java, Indonesia: Midwife versus traditional birth attendant," Women and Birth, vol. 31, no. 6, 2018, doi: 10.1016/j.wombi.2018.01.007.

[46] L. F. C. Ntoimo, F. E. Okonofua, B. Igboin, C. Ekwo, W. Imongan, and S. Yaya, "Why rural women do not use primary health centres for pregnancy care: Evidence from a qualitative study in Nigeria," $B M C$ Pregnancy Childbirth, vol. 19, no. 1, 2019, doi: 10.1186/s12884-019-2433-1.

[47] M. Arief and S. Sudikno, "DETERMINAN PEMILIHAN PERSALINAN DI FASILITAS KESEHATAN (Analisis Data Riset Kesehatan Dasar Tahun 2010)," J. Kesehat. Reproduksi, vol. 5, no. 3, 2015, doi: 10.22435/kespro.v5i3.3892.145-154.

[48] L. S. Sari, H. Husaini, and B. Ilmi, "KAJIAN BUDAYA DAN MAKNA SIMBOLIS PERILAKU IBU HAMIL DAN IBU NIFAS,” J. Berk. Kesehat., vol. 1, no. 2, p. 78, Apr. 2017, doi: 10.20527/jbk.v1i2.3146.

[49] M. Mirawati, D. R. Adila, and S. Niriyah, "GAMBARAN SIKAP IBU POSTPARTUM PADA KEPERCAYAAN BUDAYA MELAYU,” J. Ners Indones., vol. 10, no. 2, 2020, doi: 10.31258/jni.10.2.122131.

[50] M. Leta Serbesa, "Knowledge, Attitude and Practiceon Prevention of Iron Deficiency Anemia Among Pregnant Women Attending Ante Natal Care Unitat Public Hospitals of Harar Town, Eastern Ethiopia," Am. J. Heal. Res., vol. 7, no. 3, 2019, doi: 10.11648/j.ajhr.20190703.12.

[51] N. Ahmad, S. F. S. Nor, and F. Daud, "Understanding myths in pregnancy and childbirth and the potential adverse consequences: A systematic review," Malaysian J. Med. Sci., vol. 26, no. 4, 2019, doi: 10.21315/mjms2019.26.4.3.

[52] C. Sato et al., "Factors influencing the choice of facility-based delivery in the ethnic minority villages of Lao PDR: A qualitative case study," Trop. Med. Health, vol. 47, no. 1, 2019, doi: 10.1186/s41182-019-0177-2.

[53] D. G. A. Nursal and R. Kasman, "Hubungan perilaku ibu, dukungan suami dan bidan dengan kehamilan risiko tinggi di puskesmas pauh," J. Kesehat. Masy. Andalas, vol. 12 no.2, no. p-ISSN 1978-3833 e-ISSN 2442-6725, 2018.

[54] T. Tancred, T. Marchant, C. Hanson, J. Schellenberg, and F. Manzi, "Birth preparedness and place of birth in Tandahimba district, Tanzania: What women prepare for birth, where they go to deliver, and why," BMC Pregnancy Childbirth, vol. 16, no. 1, 2016, doi: 10.1186/s12884-016-0945-5.

[55] R. Shah, E. A. Rehfuess, M. K. Maskey, R. Fischer, P. B. Bhandari, and M. Delius, "Factors affecting institutional delivery in rural Chitwan district of Nepal: A community-based cross-sectional study," BMC Pregnancy Childbirth, vol. 15, no. 1, 2015, doi: 10.1186/s12884-015-0454-y.

[56] N. Kirca PhD, RN and D. Adibelli PhD, RN, "Effects of the Delivery Type on the Breastfeeding SelfEfficacy Perception," Int. J. Caring Sci., vol. 13, no. 1, 2020.

[57] A. Ao, O. Jd, and Oranu Eo, "Mothers' Reasons for Antenatal Care Registrations in Multiple Centres in the Same Pregnancy," IOSR J. Dent. Med. Sci., vol. 14, no. 4, 2015.

[58] D. Azuh, O. Fayomi, and Lady Ajayi, "Socio-Cultural Factors of Gender Roles in Women's Healthcare Utilization in Southwest Nigeria,” Open J. Soc. Sci., vol. 03, no. 04, 2015, doi: 10.4236/jss.2015.34013.

[59] E. T. Konje, J. Hatfield, S. Kuhn, R. S. Sauve, M. Magoma, and D. Dewey, "Is it home delivery or health facility? Community perceptions on place of childbirth in rural Northwest Tanzania using a qualitative approach," BMC Pregnancy Childbirth, vol. 20, no. 1, p. 270, Dec. 2020, doi: 10.1186/s12884-020-02967-z.

[60] M. C. Torri and C. Szuter, "Use of traditional medicine for maternal and child health care among women in urban Indonesia: The Jamu system and its practices in the city of Jagyakarta," BMC Complement Altern Med, vol. 17, 2017.

[61] T. Suhandoyo and D. Susanti, "Gambaran Persepsi Ibu Hamil tentang Mitos Kehamilan," J. Cent. Res. Publ. Midwifery Nurs., vol. 2, no. 2, pp. 45-51, Dec. 2018, doi: 10.36474/caring.v2i2.56.

[62] A. Zdolska-Wawrzkiewicz, M. Bidzan, M. Chrzan-Dętkoś, and D. Pizuńska, "The Dynamics of Becoming a Mother during Pregnancy and After Childbirth," Int. J. Environ. Res. Public Health, vol. 17, no. 1, p. 57, Dec. 2019, doi: 10.3390/ijerph17010057. 
International Journal of Social Science (IJSS)

Vol.1 Issue.3 October 2021, pp: 159-170

ISSN: 2798-3463 (Printed) | 2798-4079 (Online)

DOI: https://doi.org/10.53625/ijss.v1i3.408

[63] Z. Taghizadeh, "Difference in Perception of Pregnancy Risk in Two Maternal Age Groups," J. Clin. DIAGNOSTIC Res., vol. 11, no. 5, 2017, doi: 10.7860/JCDR/2017/23661.9915.

[64] S. Colley, C.-H. Kao, M. Gau, and S.-F. Cheng, "Women's perception of support and control during childbirth in The Gambia, a quantitative study on dignified facility-based intrapartum care," BMC Pregnancy Childbirth, vol. 18, no. 1, 2018, doi: 10.1186/s12884-018-2025-5.

[65] J. Y. Lee and Y. J. Jung, "PARENTAL PERCEPTIONS OF HEALTH OF PRETERM INFANTS AND FACTORS AFFECTING PERCEPTIONS ON NEONATAL HEALTH IN SINGLE UNIT,” J. Paediatr. Child Health, vol. 55, no. S1, pp. 82-82, Mar. 2019, doi: 10.1111/jpc.14410_81.

[66] L. U.M., T. I.U., and I. H., "Perceptions about Eclampsia, Birth Preparedness, and Complications Readiness among Antenatal Clients Attending a Specialist Hospital in Kano, Nigeria," J. Trop. Med., vol. 2015, 2015.

[67] K. Murakami et al., "Experiences regarding maternal age-specific risks and prenatal testing of women of advanced maternal age in Japan," Nurs. Heal. Sci., vol. 18, no. 1, 2016, doi: 10.1111/nhs.12209.

[68] A. S. H. Aji, F. Awg-Manan, Y. R. Abdullah, R. Kisut, H. Abdul Rahman, and K. H. Abdul-Mumin, "Antenatal education for pregnant women attending maternal and child health clinics in Brunei Darussalam," Women and Birth, vol. 32, no. 6, 2019, doi: 10.1016/j.wombi.2018.11.005.

[69] M. Mira Rizkia, "Hubungan Pengetahuan dengan Perilaku Ibu Hamil dalam Menjalani Kehamilan Selama Masa Pandemi Covid-19," J. Keperawatan Malang, vol. 5, no. 2, 2020, doi: 10.36916/jkm.v5i2.110.

[70] C. F. Zamawe, G. C. Masache, and A. N. Dube, "The role of the parents' perception of the postpartum period and knowledge of maternal mortality in uptake of postnatal care: A qualitative exploration in Malawi," Int. J. Womens. Health, vol. 7, 2015, doi: 10.2147/IJWH.S83228.

[71] M. Taheri, A. Takian, Z. Taghizadeh, N. Jafari, and N. Sarafraz, "Creating a positive perception of childbirth experience: Systematic review and meta-analysis of prenatal and intrapartum interventions," Reproductive Health, vol. 15, no. 1. 2018, doi: 10.1186/s12978-018-0511-x.

[72] K. Oshiro, "Experiences and Perceptions of First-time Mothers Who Conceived with Assisted Reproductive Technology and Subsequently Had Infants Who Were Admitted to the Neonatal Intensive Care Unit," 2019.

[73] M. Sultana et al., "Group prenatal care experiences among pregnant women in a Bangladeshi community," vol. 14, no. 6, 2019, doi: 10.1371/journal.pone.0218169.

[74] J. Rodríguez-Almagro, A. Hernández-Martínez, D. Rodríguez-Almagro, J. M. Quirós-García, J. M. Martínez-Galiano, and J. Gómez-Salgado, "Women's perceptions of living a traumatic childbirth experience and factors related to a birth experience," Int. J. Environ. Res. Public Health, vol. 16, no. 9, 2019, doi: 10.3390/ijerph16091654.

[75] U. T. Tugiyarti, S. S. Santoso, M. A. Akhyar, and S. A. Anantanyu, "The Relationship between Pregnant Women's Perception of the Integrated ANC Program with Pregnant Women's Behavior in the Integrated ANC Program,” Int. J. Nurs. MIDWIFERY Sci., vol. 4, no. 1, 2020, doi: 10.29082/ijnms/2020/vol4/iss1/245.

[76] M. Smorti, L. Ponti, S. Ghinassi, and G. Rapisardi, "The mother-child attachment bond before and after birth: The role of maternal perception of traumatic childbirth," Early Hum. Dev., vol. 142, p. 104956, Mar. 2020, doi: 10.1016/j.earlhumdev.2020.104956.

[77] E. N. B. R. Hutabarat and S. W. Lestari, "Pengetahuan Tanda Bahaya Kehamilan dan Perilaku Perawatan Kehamilan pada Ibu Hamil Trimester III di Puskesmas Bestari Medan Tahun 2017,” J. Ilm. Kebidanan Imelda, vol. 5, no. 2, 2019.

[78] E. Chaka, M. Parsaeian, and R. Majdzadeh, "Factors associated with the completion of the continuum of care for maternal, newborn, and child health services in Ethiopia. Multilevel model analysis," Int. J. Prev. Med., vol. 10, no. 1, 2019, doi: 10.4103/ijpvm.IJPVM_26_19.

[79] T. Puspita, "GAMBARAN PENGETAHUAN IBU HAMIL TENTANG PERAWATAN DIRI SELAMA MASA KEHAMILAN DI KABUPATEN GARUT TAHUN 2014,” J. Nurs. Public Heal., vol. 3, no. 2, 2018, doi: 10.37676/jnph.v3i2.615.

[80] Sufiyan, N. Adam, A. A. Umar, J. M. Ibrahim, S. S. Bashir, and G. Birukila, "Knowledge, attitude and perception of pregnancy danger signs among women of childbearing age in samaru community Northwestern Nigeria: Results from a cross-sectional survey," Arch. Med. Surg., vol. 1, no. 2, 2016.

[81] I. Mardiyanti and Y. Anggasari, "ANALISIS FAKTOR-FAKTOR YANG MEMPENGARUHI PERILAKU IBU HAMIL DALAM MELAKUKAN DETEKSI DINI RISIKO TINGGI KEHAMILAN,” J. Heal. Sci., vol. 13, no. 2, 2020, doi: 10.33086/jhs.v13i2.1473.

[82] D. R. Kusuma, P. D. Aryawangsa, A. B. S. Satyarsa, and P. Aryani, "PENGETAHUAN, SIKAP DAN PERILAKU IBU HAMIL TERHADAP NUTRISI SELAMA KEHAMILAN DI WILAYAH KERJA UPT PUSKESMAS MENGWI I, BADUNG, BALI," GEMA Kesehat., vol. 12, no. 1, 2020, doi: 
10.47539/gk.v12i1.127.

[83] K. B. Aditya, Y. Setiawan, and D. Puspitaningrum, "SISTEM INFORMASI GEOGRAFIS PEMETAAN FAKTOR-FAKTOR YANG MEMPENGARUHI ANGKA KEMATIAN IBU (AKI) DAN ANGKA KEMATIAN BAYI (AKB) DENGAN METODE K-MEANS CLUSTERING (STUDI KASUS: PROVINSI BENGKULU)," J. Tek. Inform., vol. 10, no. 1, 2018, doi: 10.15408/jti.v10i1.6817.

[84] N. Fatkhiyah, S. T. Rejeki, and D. Atmoko, "Kepatuhan Kunjungan Antenatal Care Berdasarkan Faktor Maternal," J. SMART Kebidanan, vol. 7, no. 1, 2020, doi: 10.34310/sjkb.v7i1.339.

[85] K. Safari, T. J. Piro, and H. M. Ahmad, "Perspectives and pregnancy outcomes of maternal Ramadan fasting in the second trimester of pregnancy," BMC Pregnancy Childbirth, vol. 19, no. 1, 2019, doi: $10.1186 / \mathrm{s} 12884-019-2275-\mathrm{x}$. 